\title{
Responses of radial growth, wood density and fiber traits to planting space in poplar plantations at a lowland site
}

\author{
Yanhua Zhang ${ }^{1} \cdot$ Shengzuo Fang ${ }^{1,2} \cdot$ Ye Tian $^{1,2}$. \\ Linlin Wang ${ }^{1} \cdot$ Yi Lv $^{1}$
}

Received: 19 January 2021 / Accepted: 20 May 2021 / Published online: 8 September 2021

(C) The Author(s) 2021

\begin{abstract}
Poplar is raw material for various panel, paper and fiber products. The 12 sample trees of clone Nanlin-895 from four spacings were destructively harvested after thirteen growing seasons to assess the influence of spacing on radial growth and wood properties. Spacing significantly affected tree-ring width and wood basic density $(p<0.05)$ but not fiber traits. The highest diameter and wood basic density at breast height $(1.3 \mathrm{~m})$ was in $6 \mathrm{~m} \times 6 \mathrm{~m}$ and $3 \mathrm{~m} \times 8 \mathrm{~m}$ spacings, respectively. However, no significant differences in tree-ring width, wood basic density and fiber traits were observed among the four sampling directions in discs taken at $1.3 \mathrm{~m}$ for each spacing. Growth rings from the pith and tree heights had significant effects on wood basic density and fiber anatomical characteristics, highlighting obvious temporal-spatial variations. Pearson correlation analysis showed a significantly negative relationship of tree-ring width to wood basic density, fiber length and fiber width, but
\end{abstract}

Project funding: The work was supported by the National Key Research and Development Program of China (Grant Number 2016YFD0600402).

The online version is available at http://www.springerlink.com

Corresponding editor: Tao $\mathrm{Xu}$

Supplementary Information The online version contains supplementary material available at https://doi.org/10.1007/ s11676-021-01382-0.

Shengzuo Fang

fangsz@njfu.edu.cn

1 College of Forestry, Nanjing Forestry University, Nanjing 210037, People's Republic of China

2 Co-Innovation Center for Sustainable Forestry in Southern China, Nanjing Forestry University, Nanjing 210037, People's Republic of China a significantly positive relationship to hemicellulose. There was no relationship with cellulose and lignin contents. Based on a comprehensive assessment by the TOPSIS method, the $6 \mathrm{~m} \times 6 \mathrm{~m}$ spacing is recommended for producing wood fiber at similar sites in the future.

Keywords Planting density - Growth ring · Fiber morphology $\cdot$ Chemical composition $\cdot$ Temporal-spatial variation

\section{Introduction}

Declining availability of wood supplies and increasing demand have prompted a renewed interest in short rotation woody crops (SRWC) around the world (Zhang et al. 2012; Wang et al. 2016a, b). With global warming however, more short-term waterlogged areas are projected (IPCC 2014), which would lead to unfavorable conditions for tree growth. One option to minimize the effects of waterlogging stress on tree growth and yield is to select species/genotypes capable of tolerating waterlogging. Populus spp. and their hybrids, due to characteristics of fast-growth and wide adaptability to various environments, are widely planted in subtropical and temperate regions in both plantation forestry and agroforestry systems (Fang et al. 2004). As the best SRWC species, the total area of poplar plantations has reached 8.54 million ha in China (IPC 2016; Tun et al. 2018), while poplar wood is mainly used as raw materials for various panel, paper and fiber products.

The chemical composition, anatomy, and morphology of raw materials influence paper and fiber products and ultimately determine its quality and appropriate end-use (Neiva et al. 2015). For example, some results indicate that fiber morphology is an important feature of papermaking, 
Table 1 General characteristics of sample trees in different planting spacing of the clone Nanlin-895. Different letters indicate significant differences $(P<0.05)$ by the Tukey test after 13 growing seasons

\begin{tabular}{llll}
\hline $\begin{array}{l}\text { Planting } \\
\text { spacing } \\
\left(\mathrm{m}^{2}\right)\end{array}$ & $\begin{array}{l}\text { Height } \\
(\mathrm{m})\end{array}$ & $\begin{array}{l}\text { Diameter at } \\
\text { breast height } \\
(\mathrm{cm})\end{array}$ & $\begin{array}{l}\text { Volume } \\
\left(\mathrm{m}^{3} \text { tree }^{-1}\right)\end{array}$ \\
\hline $6 \times 6$ & $24.03 \pm 1.24^{\mathrm{a}}$ & $27.34 \pm 0.62^{\mathrm{a}}$ & $0.60 \pm 0.06^{\mathrm{a}}$ \\
$5 \times 5$ & $23.87 \pm 1.10^{\mathrm{a}}$ & $22.86 \pm 0.24^{\mathrm{b}}$ & $0.40 \pm 0.07^{\mathrm{b}}$ \\
$4.5 \times 8$ & $24.47 \pm 1.02^{\mathrm{a}}$ & $25.33 \pm 1.31^{\mathrm{a}}$ & $0.47 \pm 0.07^{\mathrm{b}}$ \\
$3 \times 8$ & $23.43 \pm 0.87^{\mathrm{a}}$ & $22.49 \pm 0.59^{\mathrm{b}}$ & $0.39 \pm 0.06^{\mathrm{b}}$ \\
\hline
\end{tabular}

Different letters indicate significant difference among the planting spacings for the same index according to Duncan's test $(p<0.05)$

especially fiber length (Ohshima et al. 2005; Pirralho et al. 2014). This determines sheet formation, drainage properties, strength and optical properties and is correlated with various physical and mechanical properties of the wood (Young 1994; Ai and Tschirner 2010; Li et al. 2015). In addition, wood basic density (WD) is also considered one of the most important wood properties, and has a major impact on the freight costs, wood mechanical properties, pulp yield per unit mass of wood, and paper quality (Francis et al. 2006; Santos et al. 2012). It is also generally accepted that the tree volume growth (biomass accumulation) and chemical composition (e.g., cellulose, hemicellulose, and lignin) together determine the pulp yield and pulping costs (Palenik and Stupińska 2005; Mokfienski et al. 2008; Bose et al. 2009; Silva et al. 2009; Santos et al. 2012; Guo et al. 2020).

Owing to the interest of the forest industry and the large carbon stock in poplar plantations, numerous studies on suitable silvicultural techniques for poplar plantations have been carried out to get optimum yield and wood quality (Pinno et al. 2010; Benomar et al. 2012; Yang et al. 2015; Nelson et al. 2018). In practice, choosing planting spacing as an easily controlled variable is important in the silviculture of the plantation to achieve maximum biomass production, reasonable biomass partitioning, and high wood quality (Tun et al. 2018; Fang et al. 2021), when suitable genotypes are selected for a specific site. However, poplar has been widely characterized as a low-density and low strength genus (Mátyás and Peszlen 1997; Balatinecz et al. 2001), and wood from short rotation plantations is utilized as raw material for fiber board and oriented strand board as well as for the pulp and paper industry (Balatinecz et al. 2001).
Previous studies have confirmed that there are significant variations in WD, fiber morphology and chemical composition among poplar clones (Fang and Yang 2003; Fang et al. 2004, 2021), while the responses of these traits to silvicultural practices (especially spacing) were less available. Moreover, most studies of wood properties were carried out with mixed samples, ignoring the change of these traits in radial and vertical directions among tree-rings (Bose et al. 2009; Ai and Tschirner 2010; Yue et al. 2019). The influence of uneven growth of annual rings on wood density and fiber traits is particularly poorly understood (DeBell et al. 2002; Fang and Yang 2003; Fang et al. 2004; Zhang et al. 2012). Our previous study concluded that there was significant variations in tree volumes among plantations with different spacings (Zhang et al. 2020). Therefore, a comprehensive understanding of the effect of planting space on radial growth, wood density and fiber traits is vital for improving wood production and wood quality of poplar plantations. The objective of this study is to compare the differences in radial growth, WD, fiber morphology and cellulose, hemicellulose and lignin contents under different spacings, with a specific focus on the temporal-spatial variation of these properties. Results from this study would provide useful information for optimizing management of poplar plantations for high productivity and wood quality at lowland sites.

\section{Materials and methods}

\section{Study site and plantation establishment}

The study was conducted at Sihong Forest Farm, Jiangsu Province, China $\left(33^{\circ} 16^{\prime} \mathrm{N}, 118^{\circ} 18^{\prime} \mathrm{E}\right)$. Soils at this site were formed of fine sediments of Hongze Lake and have a clay loam texture with average fertility (Yan et al. 2015). The mean annual water table is approximately $0.8 \mathrm{~m}$ below the surface, with a waterlogging period of 1-2 months during the growing season. Detailed climate conditions are described by Zhang et al. (2020).

Clone Nanlin-895, a hybrid of clone I-69 (Populus deltoides Bartr. cv. 'Lux') $\times$ clone I-45 (P. $\times$ euramericana (Dode) Guinier cv. 'I-45/51'), was used as research material due to its good growth performance and adaptability at the site. A randomized block design was adopted to establish the spacing experiment with three replications. The plantations 
were established in March 2007 with one-year-old rooted cuttings at four levels of spacing $(6 \mathrm{~m} \times 6 \mathrm{~m}, 4.5 \mathrm{~m} \times 8 \mathrm{~m}$, $5 \mathrm{~m} \times 5 \mathrm{~m}$, and $3 \mathrm{~m} \times 8 \mathrm{~m}$ ) and the north-south direction is the spacing between rows, while the east-west direction is the spacing between plants. A total of 12 plots were established, ranging from 1200 to $1800 \mathrm{~m}^{2}$ to allow 50 trees per plot for each treatment. The $6 \mathrm{~m} \times 6 \mathrm{~m}$ and $5 \mathrm{~m} \times 5 \mathrm{~m}$ spacings were square configurations, while the $4.5 \mathrm{~m} \times 8 \mathrm{~m}$ and $3 \mathrm{~m} \times 8 \mathrm{~m}$ spacings were rectangular. The plantations of $6 \mathrm{~m} \times 6 \mathrm{~m}$ and $4.5 \mathrm{~m} \times 8 \mathrm{~m}$ spacing have the same planting density $\left(278\right.$ ind. ha ${ }^{-1}$ ), while the plantations with $5 \mathrm{~m} \times 5 \mathrm{~m}$ (400 ind. ha ${ }^{-1}$ ) and $3.5 \mathrm{~m} \times 8 \mathrm{~m}\left(417\right.$ ind. ha $\left.{ }^{-1}\right)$ spacings were regarded as having similar planting density.
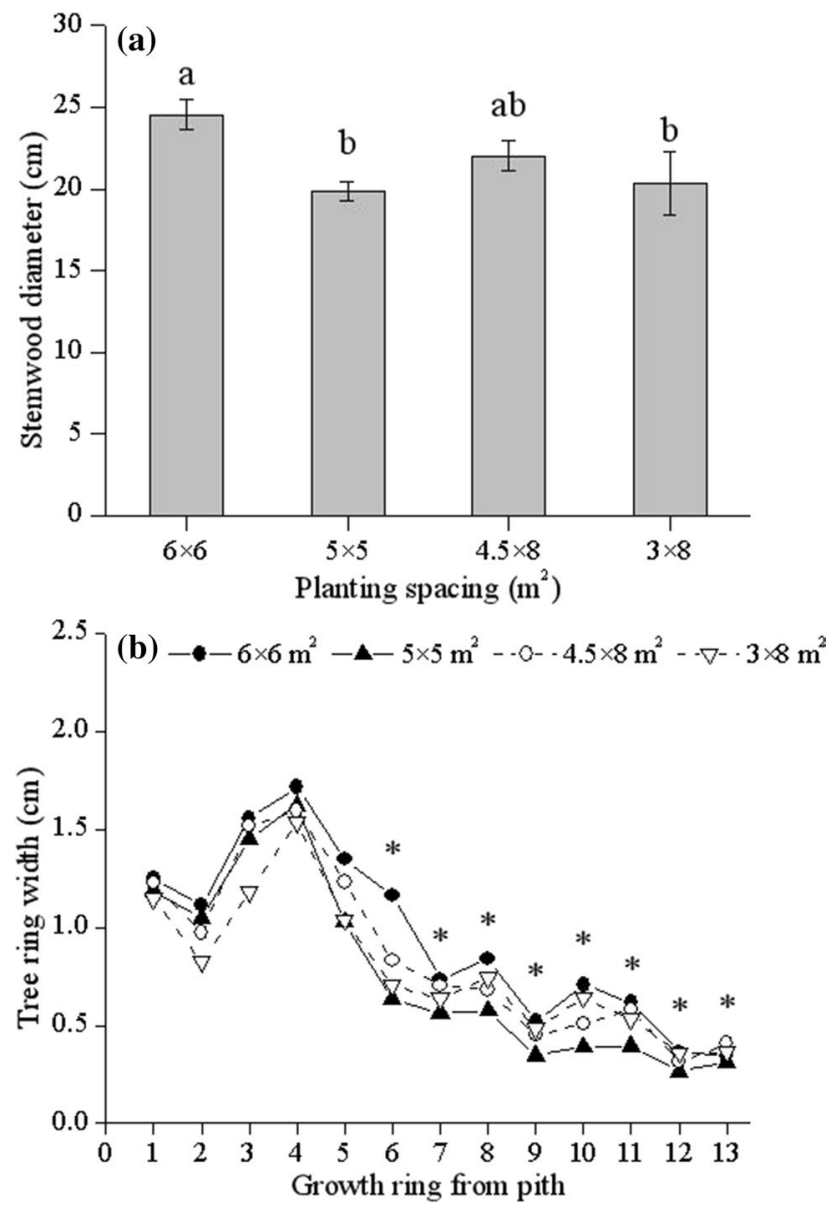

Fig. 1 a Variations in stemwood DBH after 13 growing seasons; b variations in tree-ring width under four spacings; Means with the same letters were not significantly different in Tukey test at $\alpha=0.05$. * represents a significant difference among different spacings in the same ring age $(p<0.05)$

\section{Sample tree selection and destructive sampling}

Height $(H$ in $\mathrm{m})$ and diameter at breast height ( $1.3 \mathrm{~m}$ above ground, $D B H$ in $\mathrm{cm}$ ) of all trees were measured in each plot; one sample tree of each plot was selected, based on the plot means of $D B H$ and $H$ (Table 1). A total of 12 sample trees were harvested October 2018. For each tree, five sample discs $50 \mathrm{~mm}$ thick were collected at ground level and at 1.3, and 5.6, 11.6 and $17.6 \mathrm{~m}$ (the last three representing about $25 \%, 50 \%$, and $75 \%$ of the total height, respectively). The discs were sanded to increase visualization of growth rings for measuring tree-ring width (TRW) (Menezes et al. 2003; Fang et al. 2021).

After measuring TRW, 20-mm radial strips were sampled in four directions (south, north, east and west) from $1.3 \mathrm{~m}$ discs, while the radial strips from the discs at ground level, 5.6, 11.6 and $17.6 \mathrm{~m}$ were only collected in the south direction. These sampled strips were used to measure the WD, fiber length (FL), fiber width (FW), FL/FW ratios, and the contents of cellulose, hemicellulose, and lignin.

\section{TRW and wood basic density}

Tree-ring width (TRW) was measured to the nearest $0.01 \mathrm{~mm}$ using a caliper. TRWs for all discs at $1.3 \mathrm{~m}$ were measured in four directions, while the TRWs were only measured in the south direction for the discs at ground level, 5.6, 11.6 and $17.6 \mathrm{~m}$ height. Based on the sampled strips, wood basic density (WD) for each annual tree-ring was determined by the maximum moisture content method (Smith 1954; Fang et al. 2021).

\section{Anatomical characteristics of fiber}

For the measurement of length (FL) and width (FW), a mixed sample of each annual ring, including early wood and late wood after measuring the WD, was taken. The samples were softened in a boiling 1: $1(\mathrm{v} / \mathrm{v})$ mixture of acetic acid and hydrogen peroxide for one hour and then rinsed with distilled water (Wu et al. 2013). An appropriate amount of distilled water and solarbio (staining reagent) was added, and shaken until the fibers separated. A drop of paraffin was placed on a glass slide and a dissecting needle used to transfer fibers to the slide and covered with a cover glass for a temporary mount. Fifty intact fibers of each sample were measured using a Leica digital microscope (DM 5000B, USA) based on imaging analysis of Qwin V3 software. The FW were determined at mid-length to the nearest $0.01 \mu \mathrm{m}$. 


\section{Cellulose, hemicellulose and lignin}

For the discs at $1.3 \mathrm{~m}$, two growth rings were combined into one sample from the pith outwards, whereas the outermost three rings were mixed into one sample (288 samples). However, only a mixed sample was collected from each disc at ground level, 5.6, 11.6, and $17.6 \mathrm{~m}$ (48 samples). A total of 336 samples were pulverized through a 270 -mesh sieve to measure the cellulose, hemicellulose and lignin. The cellulose content was determined according to the anthrone colorimetric method (Wang and Huang 2006), while hemicellulose and lignin contents were estimated by the hydrochloric acid hydrolysis-DNS method and the ulfuric acid titration method (Xiong et al. 2005), respectively.

\section{Statistical analysis}

The weighted means of WD, FL, FW and FL/FW in the four directions at $1.3 \mathrm{~m}$ and only in the south direction for the discs were calculated according to Eq. 1, while the weighted means of cellulose, hemicellulose and lignin were calculated by Eq. 2 .

$W_{x}=\sum x_{i} T R W_{i} / \sum T R W_{i}$

$W_{x}=\sum x_{i} T R W_{i} W D_{i} / \sum T R W_{i} W D_{i}$

where, $x$ represents WD $\left(\mathrm{g} \mathrm{cm}^{-3}\right)$, FL $(\mu \mathrm{m})$, FW $(\mu \mathrm{m})$, FL/FW and the contents of cellulose, hemicellulose and lignin (\%), respectively; $W_{x}$ is the weighted mean of these indicators.

In addition, the yield of cellulose, hemicellulose and lignin per hectare were estimated by Eq. (3):

$Y_{x}=v \times W_{W D} \times x \times n \times 1000$

where, $Y_{x}\left(\mathrm{~kg} \mathrm{ha}^{-1}\right)$ is the yield of cellulose, hemicellulose and lignin per hectare; $W_{W D}$ is the weighted mean of the discs at $1.3 \mathrm{~m}, v$ the tree volume $\left(\mathrm{m}^{3}\right.$ stem $\left.{ }^{-1}\right)$ and $n$ is the planting density (stem $\mathrm{ha}^{-1}$ ).

One-way analysis of variance (ANOVA) was performed to examine differences in TRW, WD and fiber traits among directions, tree heights and planting spacings. Comparisons of the means were conducted using Tukey's Honestly Significant Difference (HSD) test. Pearson correlation analysis was applied to examine the relationship among the weighted means of TRW, WD and fiber traits. Data are reported as the mean \pm standard deviation. All statistical analyses were carried out using Matlab2014a (Math Works Inc., Natick, MA, USA) and SPSS20.0 (SPSS Inc., Chicago, IL, USA) at $\alpha=0.05$.

TOPSIS (Technique for Order of Preference by Similarity to Ideal Solution) was used to comprehensively assess the fiber potential and quality prioritization of the four planting spacings and was implemented with the DPS v 7.05 statistical software package (Hangzhou Information Ruifeng Technology, Co., Ltd., Hangzhou, China) (Meshram et al. 2020; Fang et al. 2021).

\section{Results}

\section{Radial growth}

Stemwood diameters (without bark) at breast height were significantly affected by plant spacing after 13 growing seasons $(p<0.05$, Fig. 1a), and the highest diameter was observed in the $6 \mathrm{~m} \times 6 \mathrm{~m}(24.5 \mathrm{~cm})$ plantation and the smallest in the $5 \mathrm{~m} \times 5 \mathrm{~m}$ spacing $(19.8 \mathrm{~cm})$. The arithmetic mean over 13 years of TRW in the four spacings showed a similar order with stemwood diameters, whereas significant differences in TRW were only observed among the four planting spacings after six growing seasons $(p<0.05$, Fig. 1b). For all spacings, the dynamics of TRW displayed similar patterns, with the pith-to-bark trend leveling off around ring 11 (Fig. 1b) and TRW reaching a maximum in the fourth year.

ANOVA showed that there were no significant differences in TRW among the four directions at $1.3 \mathrm{~m}$ for each spacing ( $p>0.05$, Table S1), although slight variations were observed among the directions.

\section{Wood basic density}

Similar to tree-ring widths, there were no significant differences in wood basic density (WD) among the four directions at $1.3 \mathrm{~m}$ for each plant spacing $(p>0.05$, Table S2). 
However, WD in the east and west directions were slightly larger than in the south and north directions in $4.5 \mathrm{~m} \times 8 \mathrm{~m}$ and $3 \mathrm{~m} \times 8 \mathrm{~m}$ spacings (Fig. 2a-d). Significant differences were observed among the four spacings, with the highest WD in the $3 \times 8 \mathrm{~m}$ spacing $\left(0.3543 \mathrm{~g} \mathrm{~cm}^{-3}\right)$ and the smallest in the $5 \times 5 \mathrm{~m}$ spacing $\left(0.3374 \mathrm{~g} \mathrm{~cm}^{-3}\right)(p<0.05$, Fig. 2e). In addition, WD showed an increasing trend with growth rings from the pith but with little variability after 10 growth rings or 10 years (Fig. 2f). As shown in Fig. 2g, the mean WD significantly increased with tree height, and the highest value was at the $17.6 \mathrm{~m}$ height, reaching $0.4089 \mathrm{~g} \mathrm{~cm}^{-3}(p<0.05)$, which is $12.4 \%$ higher than that at the $1.3 \mathrm{~m}$ height.

\section{Fiber anatomical characteristics}

Planting spacing showed no significant effects on average fiber length and width, and the FL/FW ratios at breast height $(p>0.05$, Table 2$)$. In most cases, there were no significant variations in these fiber traits in the four sampling directions for each spacing (Table S3). A consistently increasing pattern was observed in the FL, FW and FL/FW ratios from the pith outwards $(p<0.05$, Fig. 3a, c). For FL and FL/FW, there was a rapid increase as is typical for juvenile wood, followed by a transition zone with slow increasing, and then the trend was relatively constant after the 10 th year (Fig. 3a, c). However, FW increased first and then stabilized after seven years (Fig. 3a). Moreover, there were significant differences in the FL, FW and FL/FW at different heights (Fig. 3b, c), showing a decreasing trend with increasing height but only a slight variation after $11.6 \mathrm{~m}$ (Fig. 3b, c).

Based on a data set of tree rings at breast height (12 trees and 624 rings), a normal distribution in percentage of FL and FL/FW by different length classes was observed for all spacings (Fig. 4). The maximum distribution in FL ranged from 1000 to $1200 \mu \mathrm{m}$ in the four planting spacings, while about $50 \%$ of the FL/FW ranged from 35 to 50 . According to the wood classification standard of the International Association of Wood Anatomists, the medium-length fiber percentage
$(900-1600 \mu \mathrm{m})$ of clone Nanlin-895 in the $6 \mathrm{~m} \times 6 \mathrm{~m}$, $5 \mathrm{~m} \times 5 \mathrm{~m}, 4.5 \mathrm{~m} \times 8 \mathrm{~m}$, and $3 \mathrm{~m} \times 8 \mathrm{~m}$ spacings were $74.7 \%$, $80.4 \%, 73.7 \%$, and $75.0 \%$, respectively. The ratio of FL/ FW 35 by spacing was $4.5 \mathrm{~m} \times 8 \mathrm{~m}(81.4 \%)>5 \mathrm{~m} \times 5 \mathrm{~m}$ $(80.2 \%)>6 \mathrm{~m} \times 6 \mathrm{~m}(77.7 \%)>3 \mathrm{~m} \times 8 \mathrm{~m}$ (76.3\%) (Fig. 4).

\section{Cellulose, hemicellulose and lignin contents}

One-way ANOVA results indicated that spacings and sampling directions did not affect the levels of cellulose, hemicellulose and lignin ( $p>0.05$, Tables 3 and S4). However, hemicellulose significantly decreased with growth rings from the pith but cellulose and lignin changed slightly (Fig. 5a). Hemicellulose levels slightly decreased with increasing tree height, whereas height did not influence cellulose, hemicellulose and lignin contents ( $p>0.05$, Fig. 5b).

\section{Discussion}

\section{Effects of planting spacing on tree ring widths, wood basic density and fiber traits}

With regards to the effects of sampling directions on TRW and wood properties, the results show no significant differences among the four sampling directions at $1.3 \mathrm{~m}$ for each spacing, except for a few growth rings of fiber anatomical characteristics (Tables S1-S4 and Fig. 2a-d). The TRW growth found in various directions are similar to the results from Tun et al. (2018) who reported no significant differences in $D B H$ between the narrow and wide spacings in rectangular configurations (such as $3 \mathrm{~m} \times 8 \mathrm{~m}$ and $4.5 \mathrm{~m} \times 8 \mathrm{~m}$ ), but mean $D B H$ in $8 \mathrm{~m}$ spacing was slightly higher than in the $4.5 \mathrm{~m}$ and $3 \mathrm{~m}$ spacings. However, relatively low planting density significantly improved radial growth, especially for the square $6 \mathrm{~m} \times 6 \mathrm{~m}$ configuration (Fig. 1a), which is supported by several studies (Lasserre et al. 2009; Tun et al. 2018; Zhang et al. 2020). In addition, TRW growth 

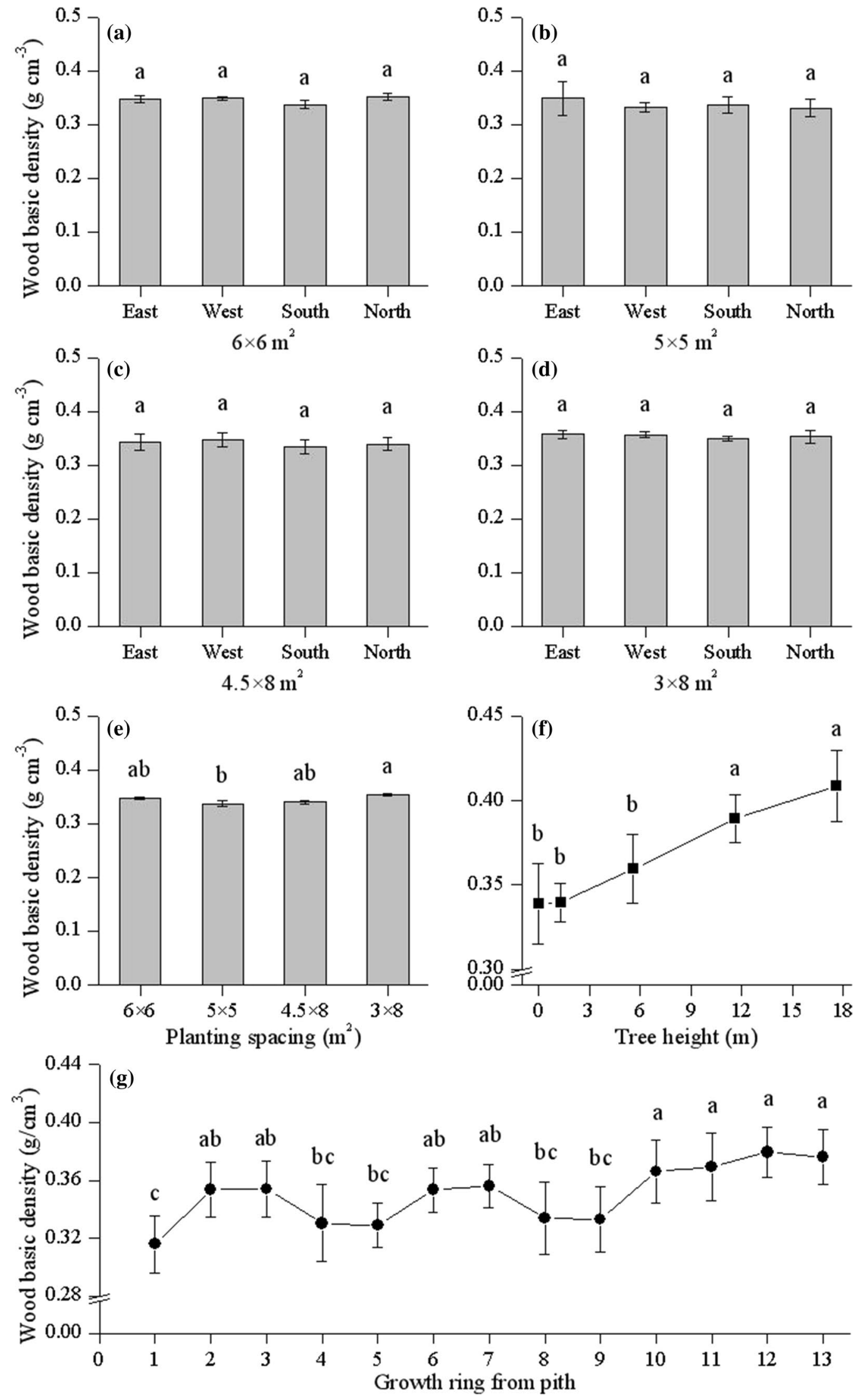
4Fig. 2 a-d Variation in weighted mean of wood basic density (WD) at breast height after 13 growing seasons among different directions for each spacing a-d, and e among the different spacings; $\mathbf{f}$ variation in mean WD at $1.3 \mathrm{~m}$ (four planting spacing averaged), and $\mathbf{g}$ the weighted means of WD at different heights; Means with the same letters were not significantly different in Tukey test at $\alpha=0.05$

responded significantly to spacing after six growing seasons (Fig. 1b). A plausible reason is that canopy competition occurred in the narrow spacing treatment and inhibited radial growth (Tun et al. 2018; Ahmed et al. 2020; Zhang et al. 2020). Furthermore, compared to the results at a lowland site reported by Fang et al. (2021), poplar growth rate in this study is much lower owing to differences in clones and water table levels between the two sites. Our results are in agreement with previous reports that both groundwater levels and soil moisture impact radial growth of different tree species (Orwig and Abrams 1997; He et al. 2020; Heilig et al. 2021). Likewise, the significant effect of plant spacing on WD was found in the present study at the stand age of 13, which is inconsistent with some reports of wood air-dry density and oven-dried density for conifer species (Lasserre et al. 2009; Watson et al. 2011) where WD was not significantly influenced by plant spacings, confirming that, except for spacing, wood air-dry density (density when wood is equilibriated to $40 \% \mathrm{RH}$ and $20{ }^{\circ} \mathrm{C}$; equivalent to $7-8 \%$ moisture content) is affected by other factors such as species, genotype and site conditions (Pliura et al. 2007). In the fiber traits, Watson et al. (2011) noted that the outer fiber length of coastal western hemlock was significantly shorter at the widest spacing, while Lasserre et al. (2009) found that fiber width of Pinus radiata D. Don was not significantly different among spacing treatments. Fiber length and FL/ FW ratios were higher (up to 33\%) in the clone Nanlin-895 compared to clones of Populus tomentosa Carr. in northern China (Wu et al. 2013), and average precipitation was about half of this study site. Previous studies also reported a significant site effect (including annual precipitation) in fiber morphology, holocellulose and lignin content of Dendrocalamus giganteus Munro (Wang et al. 2016a, b). However, our study indicated that plant spacing did not influence fiber anatomical characteristics and cellulose, hemicellulose and lignin contents (Tables 2 and 3), suggesting that the poplar clone had less phenotypic plasticity in fiber traits.

\section{Temporal-spatial variations in wood basic density and fiber traits}

In this study, fiber anatomical characteristics had a gradually increasing tendency from pith to bark (Fig. 3a, c), showing a strong influence of cambial age on these properties in agreement with previous research (Yanchuk et al. 1984; Fang and Yang 2003; Fang et al. 2004). This is possibly due to the increase in size of cambial initials with age that is related to the development of the stem (Ilona 1994). Nevertheless, cellulose and lignin contents did not change significantly from the pith to the bark, remaining relatively constant, whereas hemicellulose decreased from the pith (Fig. 5a).

In addition, our results found that the average fiber length decreased with increasing tree height (Fig. 3b), which is in accordance with Fang and Yang (2003), and further shows that cambium age is an important factor regulating fiber length. However, average WD showed a general increase with increasing tree height (Fig. 2g), in line with previous studies (Fang and Yang 2003; Fang et al. 2021). This spatial variation pattern in WD is possibly related to the proportions of juvenile and mature wood. Juvenile wood generally accounts for a large proportion in the lower trunk (Elspeth and Jason 2002), while there were higher contents of lignin and $\mathrm{NaOH}$ extractives in juvenile wood compared to mature wood (Pitre et al. 2007; Wu et al. 2011). Larson (1964) indicated that wood density was related to plant nutritional status, and the top of the stem was easier receive nutrients produced by canopy photosynthesis.

Our study highlights that growth rings from the pith outwards and tree height have significant effects on WD and some fiber traits (Figs. 2f, g, 3 and 5), while plant spacing did not significantly affect average WD and fiber traits except for WD in the $5 \mathrm{~m} \times 5 \mathrm{~m}$ spacing (Fig. 2e, Tables 2 and 3 ), indicating that the main factors driving wood formation were the developmental stage and genetic qualities (Pitre et al. 2007; Watt et al. 2008; Lasserre et al. 2009; Silva et al. 2009). Our results, however, did not find a significant 
Table 2 Effects of planting space on weighted means of fiber anatomical characteristics at breast height

\begin{tabular}{llll}
\hline $\begin{array}{l}\text { Planting spacing } \\
\left(\mathrm{m}^{2}\right)\end{array}$ & $\begin{array}{l}\text { Fiber length (FL) } \\
(\mu \mathrm{m})\end{array}$ & $\begin{array}{l}\text { Fiber width } \\
(\mathrm{FW}) \\
(\mu \mathrm{m})\end{array}$ & FL/FW \\
\hline $6 \times 6$ & $1051.34 \pm 7.05^{\mathrm{a}}$ & $25.60 \pm 0.28^{\mathrm{a}}$ & $41.82 \pm 0.45^{\mathrm{a}}$ \\
$5 \times 5$ & $1049.40 \pm 20.00^{\mathrm{a}}$ & $26.00 \pm 1.00^{\mathrm{a}}$ & $41.10 \pm 1.50^{\mathrm{a}}$ \\
$4.5 \times 8$ & $1059.77 \pm 34.30^{\mathrm{a}}$ & $24.66 \pm 0.62^{\mathrm{a}}$ & $44.24 \pm 2.55^{\mathrm{a}}$ \\
$3 \times 8$ & $1060.90 \pm 19.56^{\mathrm{a}}$ & $26.16 \pm 2.08^{\mathrm{a}}$ & $41.35 \pm 2.70^{\mathrm{a}}$ \\
\hline
\end{tabular}

The same letters for the same index indicate no significant difference among the planting spacings according to Tukey test at $\alpha=0.05$

spatial variation in cellulose, hemicellulose and lignin levels at different tree heights (Fig. 5b).

\section{Correlations among the measured variables}

Numerous studies indicate some relationships between tree growth and wood properties (Farmer and Wilcox 1966; Zhang et al. 2003; Lasserre et al. 2009; Ahmed et al. 2020). However, the results from these previous studies on the relationship of tree growth, wood density and fiber traits were often controversial. For instance, Zhang et al. (2003) and Lasserre et al. (2009) reported that there was no significant correlation between growth traits and wood air-dry density. Farmer and Wilcox (1966) and Watt et al. (2005) found that radial growth rate was negatively correlated with wood ovendried density and air-dry density in poplars and $P$. radiata, consistent with our study (Table 4), but DeBell et al. (2004) indicated the negative correlation between growth rate and wood oven-dry density diminished with increasing tree age.
Additionally, our results clearly show that tree-ring width (TRW) was significantly and negatively correlated with fiber anatomical characteristics, whereas a significantly positive correlation existed between WD and fiber anatomical traits (Table 4), in agreement with other studies (Fang et al. 2004; Lasserre et al. 2009). This was inconsistent with the results of Ahmed et al. (2020) where a positive relationship between growth traits and fiber length was found. Moreover, there were significantly positive correlations between TRW and hemicellulose content and a negative relationship between WD and lignin content (Table 4). This is inconsistent with the results of Ona et al. (1997) and Ahmed et al. (2020). Furthermore, only a significantly negative correlation between cellulose and lignin contents was found among three wood chemical compositions (Table 4). Overall, our results suggest that tree growth and wood properties such as density, fiber characteristics and chemical compositions are not genetically independent. Therefore, both genetic and management measures (such as spacing) should be considered to improve wood quality and yield in future afforestation with poplar.

\section{Assessments of potential pulp and paper making}

Wood quality is the result of physical and chemical characteristics of a tree or parts of a tree that provide the property requirements for different end products (Briggs and Smith 1986). The potential of poplar as a feedstock for pulp and paper making depends on the quantitative and qualitative characteristics of fiber morphology, holocellulose biomass and total biomass production (Young 1994; Ai and Tschirner 2010; Santos et al. 2012; Pirralho et al. 2014; Neiva et al. 
Fig. 3 Variation in mean fiber length (FL), fiber width (FW) and FL/FW at $1.3 \mathrm{~m}$ (a and $\mathbf{c}$, four planting spacing averaged), and the weighted means of fiber anatomical characteristics at different tree heights (b and $\mathbf{c})$; Means with the same letters were not significantly different in the Tukey test at $\alpha=0.05$
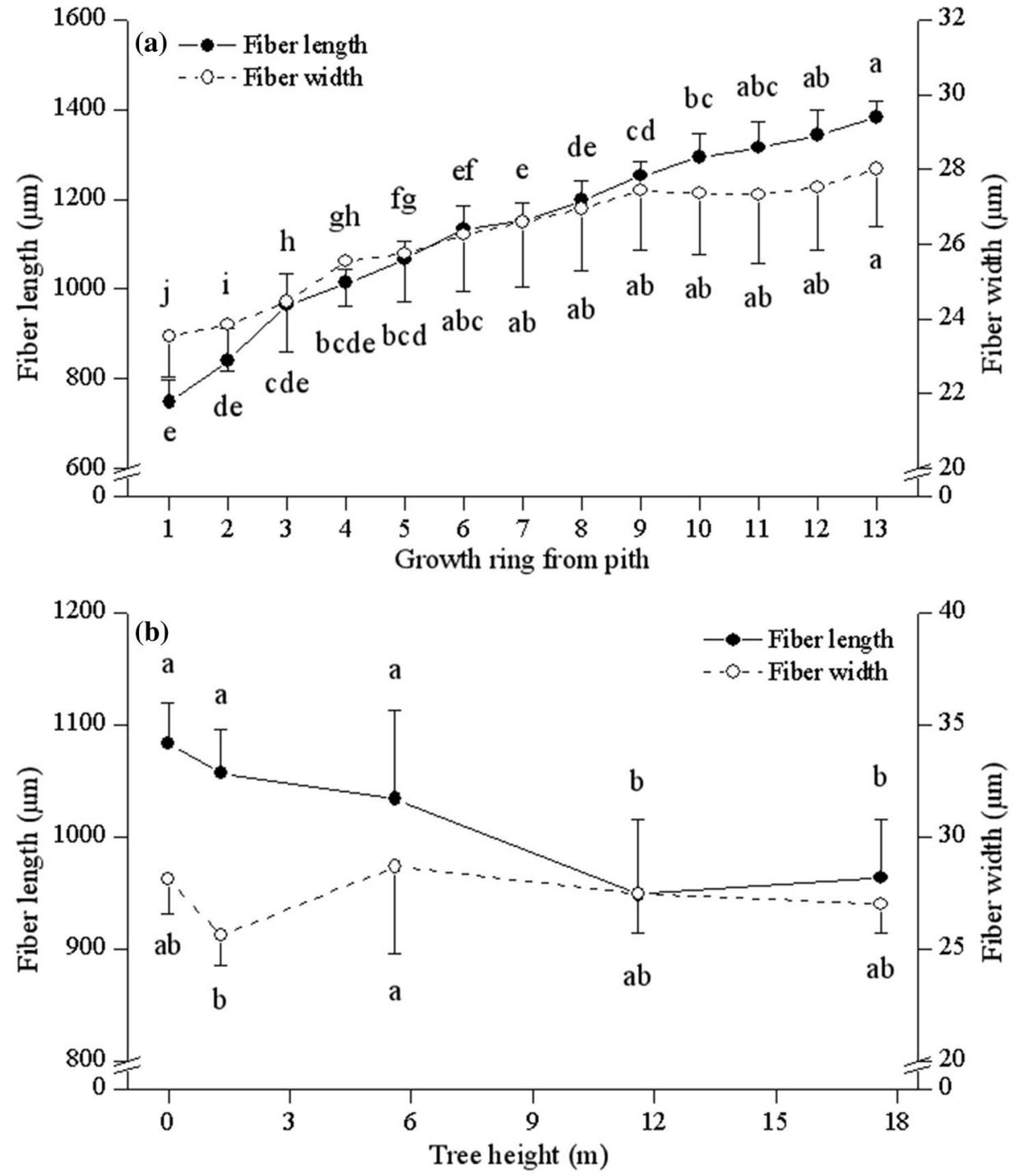

Growth ring from pith

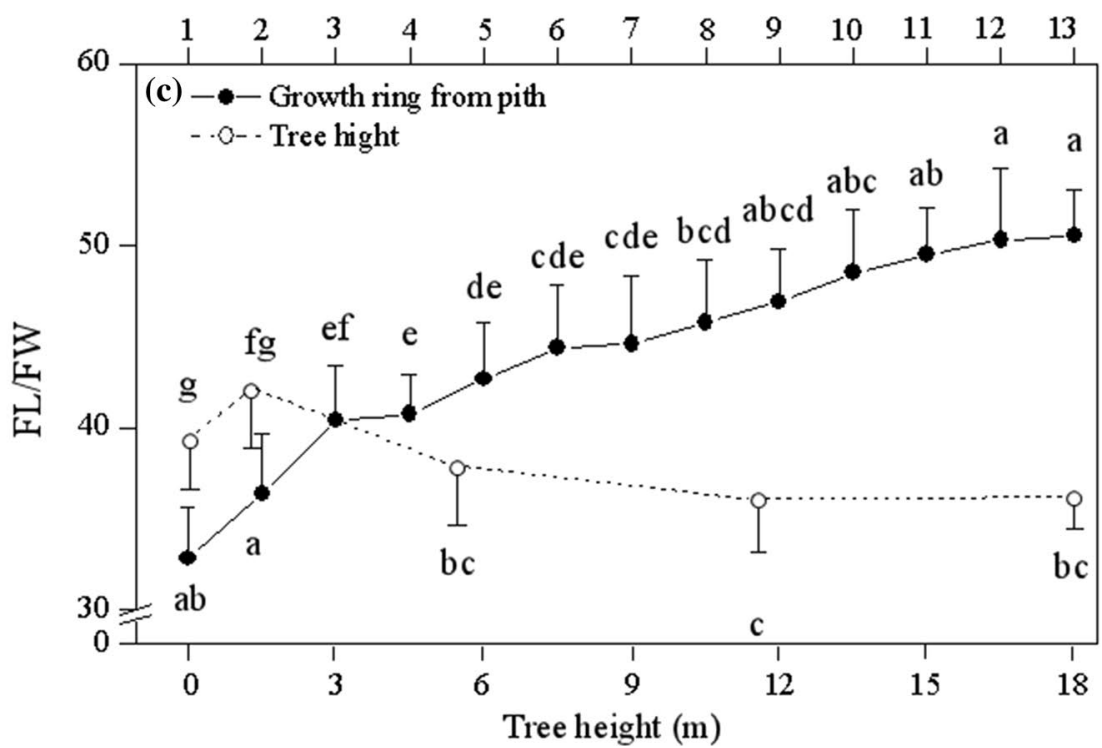


Fig. 4 a fiber length and b FL/ FW (fiber length/ fiber width) distribution of all tree-rings at breast height in four spacings
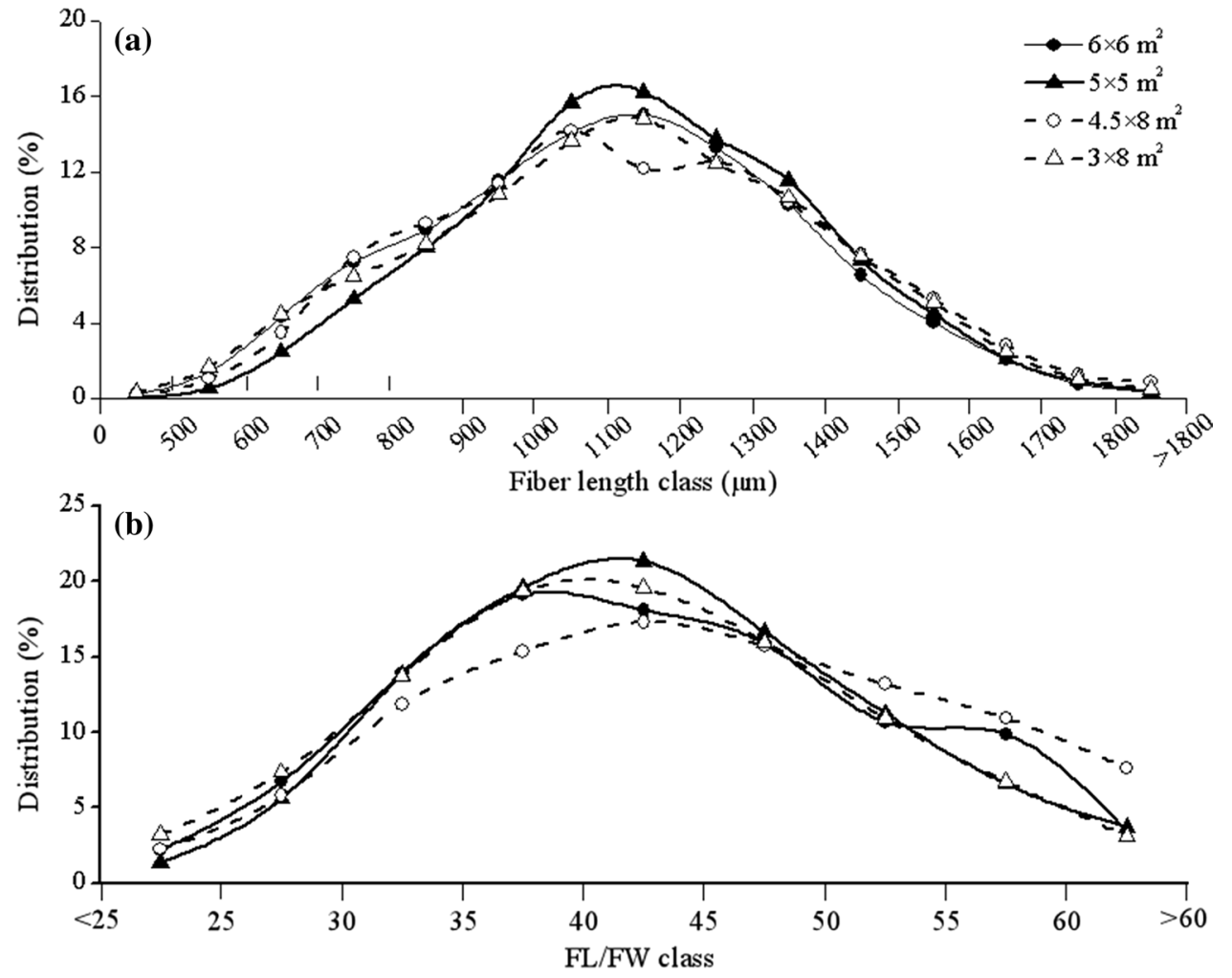

Table 3 Effects of planting spacing on the means of cellulose, hemicellulose and lignin contents at breast height

\begin{tabular}{llll}
\hline $\begin{array}{l}\text { Planting } \\
\text { spacing } \\
\left(\mathrm{m}^{2}\right)\end{array}$ & $\begin{array}{l}\text { Cellulose } \\
\text { content } \\
(\%)\end{array}$ & $\begin{array}{l}\text { Hemicellulose } \\
\text { content } \\
(\%)\end{array}$ & $\begin{array}{l}\text { Lignin } \\
\text { content } \\
(\%)\end{array}$ \\
\hline $6 \times 6$ & $45.24 \pm 3.64^{\mathrm{a}}$ & $17.07 \pm 0.52^{\mathrm{a}}$ & $31.62 \pm 5.59^{\mathrm{a}}$ \\
$5 \times 5$ & $43.27 \pm 2.11^{\mathrm{a}}$ & $16.90 \pm 0.61^{\mathrm{a}}$ & $33.98 \pm 4.69^{\mathrm{a}}$ \\
$4.5 \times 8$ & $42.97 \pm 1.12^{\mathrm{a}}$ & $16.27 \pm 0.78^{\mathrm{a}}$ & $28.23 \pm 6.15^{\mathrm{a}}$ \\
$3 \times 8$ & $44.01 \pm 1.10^{\mathrm{a}}$ & $15.85 \pm 1.33^{\mathrm{a}}$ & $32.40 \pm 4.16^{\mathrm{a}}$ \\
\hline
\end{tabular}

The same letters for the same index indicate no significant difference among the planting spacings according to Tukey test at $\alpha=0.05$
2015). For example, kraft pulp yield is highly correlated with cellulose, holocellulose and wood basic density, but low lignin levels would be preferred for several reasons $\mathrm{CHu}$ et al. 1999; Francis et al. 2006; Bose et al. 2009; Neiva et al. 2015). At the same time, it is universally acknowledged that tear index depends strongly on fiber length and higher FL/ FW wood fiber with superior printing properties (Young 1994; Ai and Tschirner 2010). In this study, the yield of cellulose and hemicellulose per hectare and fiber characteristics at breast height were positive variables, and the lignin yield per hectare was negative variable. An assessment for paper 
Fig. 5 Variation in mean contents of cellulose, hemicellulose and lignin at $1.3 \mathrm{~m}$ (a, four planting spacing averaged) and the weighted means of chemical contents at different tree height b for 12 sampled poplar trees, means with the same letters were not significantly different in Tukey test at $\alpha=0.05$
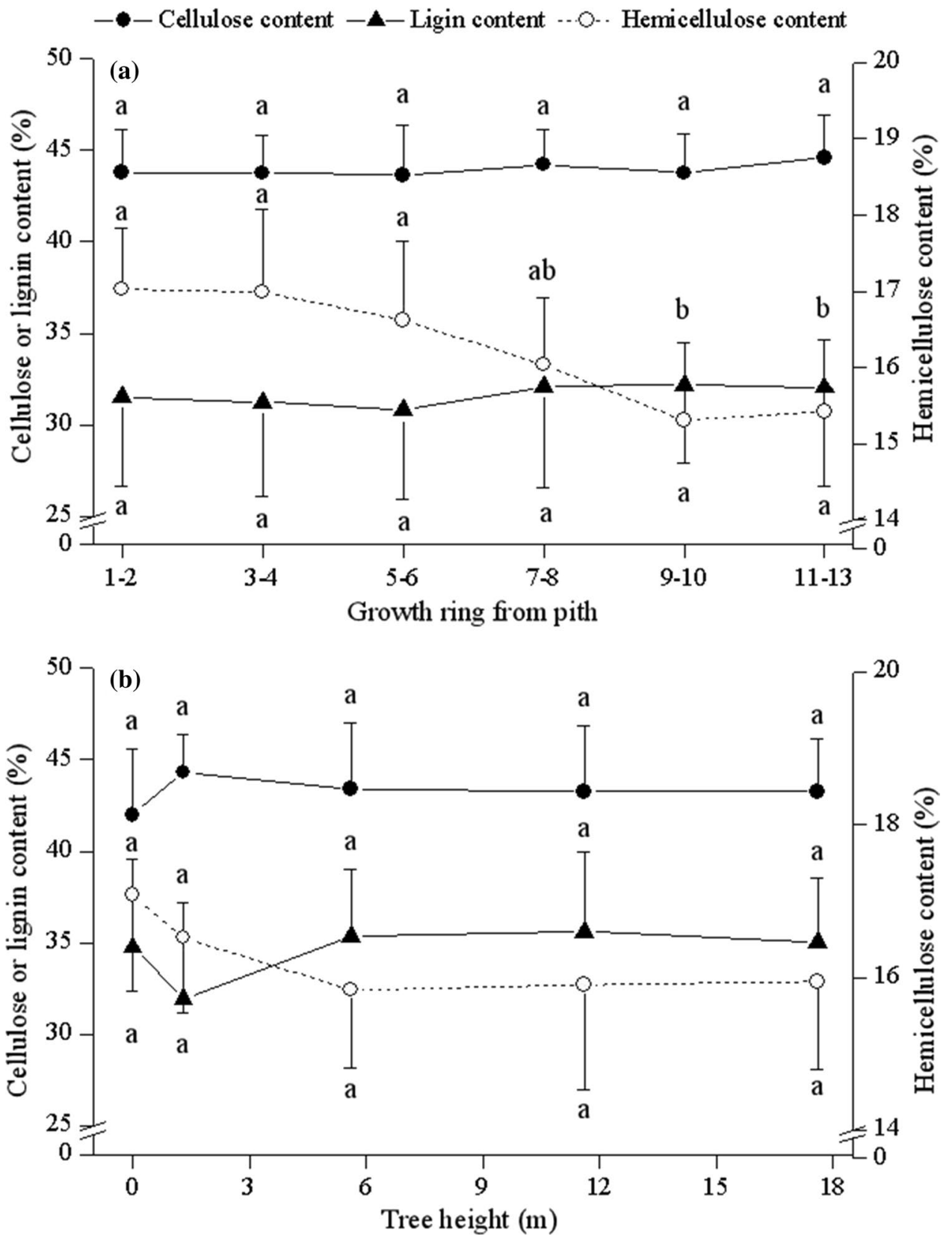
Table 4 Pearson correlations among measured variables based on data at breast height $(n=288)$; weighted averages of TRW, WD and fiber anatomical characteristics were based on the combined sample method for determination of cellulose, hemicellulose and lignin contents

\begin{tabular}{|c|c|c|c|c|c|c|c|}
\hline Variables & Tree-ring width & WD & FL & FW & $\mathrm{FL} / \mathrm{FW}$ & $\mathrm{LC}$ & $\mathrm{HC}$ \\
\hline Wood basic density (WD) & $-0.243 * *$ & & & & & & \\
\hline Fiber length (FL) & $-0.639 * *$ & $0.362 * *$ & & & & & \\
\hline Fiber width $(\mathrm{FW})$ & $-0.435 * *$ & $0.148 *$ & $0.638 * *$ & & & & \\
\hline FL/FW & $-0.526 * *$ & $0.372 * *$ & $0.859 * *$ & $0.161 * *$ & & & \\
\hline Lignin content (LC) & -0.080 & $-0.122 *$ & 0.005 & -0.067 & 0.038 & & \\
\hline Hemicellulose content (HC) & $0.460 * *$ & -0.008 & $-0.455^{* *}$ & $-0.117^{*}$ & $-0.489 * *$ & -0.115 & \\
\hline Cellulose content (CC) & -0.047 & 0.103 & 0.066 & -0.045 & $0.127 *$ & $-0.169 * *$ & -0.076 \\
\hline
\end{tabular}

$* p<0.05$

$* * p<0.001$.

Table 5 An assessment of optimal paper pulp and prioritization of four planting spacings by the TOPSIS method

\begin{tabular}{lllll}
\hline $\begin{array}{l}\text { Planting spacing } \\
\left(\mathrm{m}^{2}\right)\end{array}$ & $d_{f}^{+}$ & $d_{i}^{-}$ & $\mathrm{C}_{i}$ & $\begin{array}{l}\text { Ranking } \\
\text { order }\end{array}$ \\
\hline $6 \times 6$ & 0.1996 & 0.2091 & 0.5117 & 1 \\
$5 \times 5$ & 0.2118 & 0.1231 & 0.3676 & 4 \\
$4.5 \times 8$ & 0.2102 & 0.202 & 0.4901 & 2 \\
$3 \times 8$ & 0.2095 & 0.1572 & 0.4287 & 3 \\
\hline
\end{tabular}

pulp and prioritization of different planting spacings was conducted by the TOPSIS method (Table 5). Findings indicate that a $6 \mathrm{~m} \times 6 \mathrm{~m}$ spacing should be recommended for future poplar silviculture for pulp production at similar sites.

\section{Conclusions}

Planting spacing significantly influenced tree-ring width and average wood basic density significantly increased with tree height $(p<0.05)$. Wider spacing increased radial growth but not wood basic density. No significant differences in fiber traits were detected among the four spacings. For each spacing, wood sampling directions at $1.3 \mathrm{~m}$ height had no significant effects on tree-ring width, wood basic density and fiber traits. Results from this study show that growth rings and tree heights had significant effects on the wood basic density and fiber anatomy, highlighting obvious temporalspatial variations in wood basic density and some fiber traits. Pearson correlation analysis showed a significantly negative relationship of tree-ring width to wood basic density, and fiber length and width, a significantly positive relationship between tree-ring width and hemicellulose content, and no effect of tree-ring width on cellulose and lignin contents. Based on a comprehensive assessment by the TOPSIS method, a $6 \mathrm{~m} \times 6 \mathrm{~m}$ spacing is recommended for future the establishment of poplar plantations for pulp and papermaking on similar sites.

Acknowledgements We would like to thank Caowen Sun, Jian Qin, Xiliang Yue, Wagle Samjhana and other graduate students from Nanjing Forestry University for their assistance with the laboratory work.

Open Access This article is licensed under a Creative Commons Attribution 4.0 International License, which permits use, sharing, adaptation, distribution and reproduction in any medium or format, as long as you give appropriate credit to the original author(s) and the source, provide a link to the Creative Commons licence, and indicate if changes were made. The images or other third party material in this article are included in the article's Creative Commons licence, unless indicated otherwise in a credit line to the material. If material is not included in the article's Creative Commons licence and your intended use is not permitted by statutory regulation or exceeds the permitted use, you will need to obtain permission directly from the copyright holder. To view a copy of this licence, visit http://creativecommons. org/licenses/by/4.0/.

\section{References}

Ahmed AKM, Fu ZX, Ding CJ, Jiang LP, Han XD, Yang AG, Ma YH, Zhao XY (2020) Growth and wood properties of a 38-yearold Populus simonii $\times$ P. nigra plantation established with different densities in semi-arid areas of northeastern China. $\mathbf{J}$ for Res 31(2):497-506

Ai J, Tschirner U (2010) Fiber length and pulping characteristics of switchgrass, alfalfa stems, hybrid poplar and willow biomasses. Bioresour Technol 101(1):215-221

Balatinecz JJ, Kretschmann DE, Leclercq A (2001) Achievements in the utilization of poplar wood-guideposts for the future. For Chron 77(2):265-269

Benomar L, DesRochers A, Larocque GR (2012) The effects of spacing on growth, morphology and biomass production and allocation in two hybrid poplar clones growing in the boreal region of Canada. Trees 26(3):939-949

Bose SK, Francis RC, Govender M, Bush T, Spark A (2009) Lignin content versus syringyl to guaiacyl ratio amongst poplars. Bioresour Technol 99(4):1628-1633

Briggs DG, Smith WR (1986) Effect of silvicultural practices on wood properties of conifers: a review. Douglas- fir: stand management 
for the future. University of Washington Press, Seattle, pp 108-117

DeBell DS, Singleton R, Harrington CA, Gartner BL (2002) Wood density and fiber length in young Populus stems: relation to clone, age, growth rate, and pruning. Wood Fiber Sci 34(4):529-539

DeBell DS, Singleton R, Gartner BL, Marshall DD (2004) Wood density of young-growth western hemlock: relation to ring age, radial growth, stand density, and site quality. Can J for Res 34(12):2433-2442

Elspeth M, Jason H (2002) A review of the effects of silviculture on timber quality of Sitka spruce. Forestry 75(2):107-138

Fang SZ, Yang WZ (2003) Interclonal and within-tree variation in wood properties of poplar clones. J for Res 14(4):263-268

Fang SZ, Yang WZ, Fu XX (2004) Variation of microfibril angle and its correlation to wood properties in poplars. J for Res 15(4):261-267

Fang SZ, Liu Y, Yue J, Tian Y, Xu XZ (2021) Assessments of growth performance, crown structure, stem form and wood property of introduced poplar clones: Results from a long-term field experiment at a lowland site. For Ecol Manage 479:118586

Farmer REJ, Wilcox JR (1966) Specific gravity variation in a lower Mississippi valley cottonwood population. Tappi 49:210-211

Francis R, Hanna R, Shin S, Brown A, Riemenschneider D (2006) Papermaking characteristics of three Populus clones grown in the north-central United States. Biomass Bioenerg 30(8-9):803-808

Guo XH, Fu YJ, Miao FW, Yu QS, Zhang FS (2020) Efficient separation of functional xylooligosaccharide, cellulose and lignin from poplar via thermal acetic acid/sodium acetate hydrolysis and subsequent kraft pulping. Ind Crops Prod 153:112575

He YL, Xi BY, Bloomberg M, Jia LM, Zhao DH (2020) Effects of drip irrigation and nitrogen fertigation on stand growth and biomass allocation in young triploid Populus tomentosa plantations. For Ecol Manage 461:117937

Heilig D, Heil B, Leibing C, Röhle H, Kovács G (2021) Comparison of the initial growth of different poplar clones on four sites in Western Slovakia—preliminary results. J Bioenerg Res 14:374-384

Hu WJ, Harding SA, Lung J, Popko JL, Ralph J, Stokke DD, Tsai CJ, Chiang VL (1999) Repression of lignin biosynthesis promotes cellulose accumulation and growth in transgenic trees. Nat Biotechnol 17(8):808-812

Ilona P (1994) Influence of age on selected anatomical properties of Populus clones. IAWA J 15(3):311-321

IPC (International Poplar Commission) (2016) Poplar and other fastgrowing trees -renewable resources for future green economies. Synthesis of country progress reports. In: Proceedings of the " 25 th Session of the International Poplar Commission". Berlin, Germany.

IPCC (2014) Climate Change (2014) Synthesis Report. Contribution of working groups I, II and III to the fifth assessment report of the Intergovernmental Panel on Climate Change. IPCC, Geneva.

Larson PR (1964) Some indirect effects of environment on wood formation. Academic Press, Pittsburgh, pp 345-365

Lasserre JP, Mason EG, Watt MS, Moore JR (2009) Influence of initial planting spacing and genotype on microfibril angle, wood density, fibre properties and modulus of elasticity in Pinus radiata D. Don Corewood for Ecol Manage 258(9):1924-1931

Li JH, Zhang HJ, Li JG, Hu HR, Cao ZL (2015) Fiber characteristics and bonding strength of poplar refiner-chemical preconditioned alkaline peroxide mechanical pulp fractions. BioResources 10(2):3702-3712

Mátyás C, Peszlen I (1997) Effect of age on selected wood quality traits of poplar clones. Silvae Genet 46(2):64-72

Menezes M, Berger U, Worbes M (2003) Annual growth rings and long-term growth patterns of mangrove trees from the Bragança Peninsula. North Brazil Wetlands Ecol Manage 11(4):233-242
Meshram SG, Alvandi E, Meshram C, Kahya E, Fadhil Al-Quraishi A (2020) Application of SAW and TOPSIS in prioritizing watersheds. Water Resour Manage 34(2):715-732

Mokfienski A, Colodette JL, Gomide JL, Carvalho AMM (2008) Relative importance of wood density and carbohydrate content on pulping yield and product quality. Cienc Florest 18(3):401-413

Neiva D, Fernandes L, Araújo S, Lourenço A, Gominho J, Simões R, Pereira H (2015) Chemical composition and kraft pulping potential of 12 eucalypt species. Ind Crops Prod 66:89-95

Nelson ND, Berguson WE, McMcMahon BG, Cai MJ, Buchman DJ (2018) Growth performance and stability of hybrid poplar clones in simultaneous tests on six sites. Biomass Bioenergy 115:115-125

Ohshima J, Yokota S, Yoshlzawa N, Ona T (2005) Representative heights for assessing whole-tree values and the within-tree variations of derived wood properties in Eucalyptus camaldulensis and E. globulus. Wood Fiber Sci 37(1):51-65

Ona T, Sonoda T, Ito K, Shibata M (1997) Relationship between various extracted basic densities and wood chemical components in Eucalyptus camaldulensis. Wood Sci Technol 31(3):205-216

Orwig DA, Abrams MD (1997) Variation in radial growth responses to drought among species, site, and canopy strata. Trees 11(8):474-484

Palenik J, Stupińska H (2005) Assessing the suitability of wood from the hybrid trees of a poplar and a willow for manufacturing the papermaking pulps. For Wood Technol 112(5):1199-1208

Pinno BD, Thomas BR, Bélanger N (2010) Predicting the productivity of a young hybrid poplar clone under intensive plantation management in northern Alberta, Canada using soil and site characteristics. New for 39(1):89-103

Pirralho M, Flores D, Sousa VB, Quilhó T, Knapic S, Pereira H (2014) Evaluation on paper making potential of nine Eucalyptus species based on wood anatomical features. Ind Crops Prod 54:327-334

Pitre FE, Cooke JEK, Mackay JJ (2007) Short-term effects of nitrogen availability on wood formation and fibre properties in hybrid poplar. Trees 21(2):249-259

Pliura A, Zhang SY, MacKay J, Bousquet J (2007) Genotypic variation in wood density and growth traits of poplar hybrids at four clonal trials. For Ecol Manage 238(1-3):92-106

Santos A, Anjos O, Amaral ME, Gil N, Pereira H, Simões R (2012) Influence on pulping yield and pulp properties of wood density of Acacia melanoxylon. J Wood Sci 58:479-486

Silva JCE, Borralho NMG, Araujo JA, Vaillancourt RE, Potts BM (2009) Genetic parameters for growth, wood density and pulp yield in Eucalyptus globulus. Tree Genet Genomes 5(2):291-305

Smith DM (1954) Maximum moisture content method for determining specific gravity of small wood samples. USDA Forest Service, Forest Product Laboratory Report No, p 2014

Tun TN, Guo J, Fang SZ, Tian Y (2018) Planting spacing affects canopy structure, biomass production and stem roundness in poplar plantations. Scand J for Res 33(5):464-474

Wang SG, Lin SY, Li WC, Ding YL (2016a) Variations in fiber morphology and chemical components of Dendrocalamus giganteus. For Prod J 66(5-6):319-325

Wang YR, Liu CW, Zhao RJ, McCord J, Rials T, Wang SQ (2016b) Anatomical characteristics, microfibril angle and micromechanical properties of cottonwood (Populus deltoides) and its hybrids. Biomass Bioenergy 93:72-77

Wang XK, Huang JL (2006) Principle and technology of plant physiological and biochemical experimen. Higher Education Press, Beijing, p 222-223. (In Chinese)

Watson P, Garner C, Robertson R, Reath S, Gee W, Hunt K (2011) The effects of initial tree spacing on the fibre properties of plantationgrown coastal western hemlock. Can J for Res 33:2460-2468

Watt MS, Downes GM, Whitehead D, MasonEG RB, Grace JC, Moore JR (2005) Wood properties of juvenile Pinus radiata growing in 
the presence and absence of competing understorey vegetation at a dryland site. Trees 19(5):580-586

Watt MS, D'Ath R, Leckie AC, Clinton PW, Coker G, Davis MR, Simcock R, Pafitt RL, Dando J, Mason EG (2008) Modelling the influence of stand structural, edaphic and climatic influences on juvenile Pinus radiata fibre length. For Ecol Manage 254(2):166-177

Wu H, Liu SQ, Zha CS, Yu YS (2011) Comparative study on the chemical composition between juvenile and mature wood of different poplar clones. J Northwest Agr for Univ 39(7):71-76 (In Chinese)

Wu F, Zhang PD, Pei JC, Kang XY (2013) Genotypic parameters of wood density and fiber traits in triploid hybrid clones of Populus tomentosa at five clonal trials. Ann for Sci 70(7):751-759

Xiong SM, Zuo XF, Zhu YY (2005) Determination of cellulose, hemicellulose and lignin in rice hull. Cereal Feed Ind 8:40-41 (In Chinese)

Yan YF, Fang SZ, Tian Y, Deng SP, Tang LZ, Chuong DN (2015) Influence of tree spacing on soil nitrogen mineralization and availability in hybrid poplar plantations. Forests 6(12):636-649

Yanchuk AD, Dancik BP, Micko MM (1984) Variation and heritability of wood density and fibre length of trembling aspen in Alberta. Canada Silvae Genet 33(1):11-16

Yang YN, Jiang H, Wang ML, Korpelainen H, Li CY (2015) Male poplars have a stronger ability to balance growth and carbohydrate accumulation than do females in response to a short-term potassium deficiency. Physiol Plant 155:400-413

Young RA (1994) Comparison of the properties of chemical cellulose pulps. Cellulose 1(2):107-130

Yue Z, Hou QX, Liu W, Yu SY, Wang XD, Zhang HL (2019) Autohydrolysis prior to poplar chemi-mechanical pulping: Impact of surface lignin on subsequent alkali impregnation. Bioresour Technol 282:318-324

Zhang SY, Yu QB, Chauret G, Koubaa A (2003) Selection for both growth and wood properties in hybrid poplar clones. For Sci 49(6):901-908

Zhang PD, Wu F, Kang XY (2012) Genotypic variation in wood properties and growth traits of triploid hybrid clones of Populus tomentos $a$ at three clonal trials. Tree Genet Genomes 8(5):1041-1050

Zhang YH, Tian Y, Ding SH, Lv Y, Samjhana W, Fang SZ (2020) Growth, carbon storage, and optimal rotation in poplar plantations: a case study on clone and planting spacing effects. Forests 11:842

Publisher's Note Springer Nature remains neutral with regard to jurisdictional claims in published maps and institutional affiliations. 